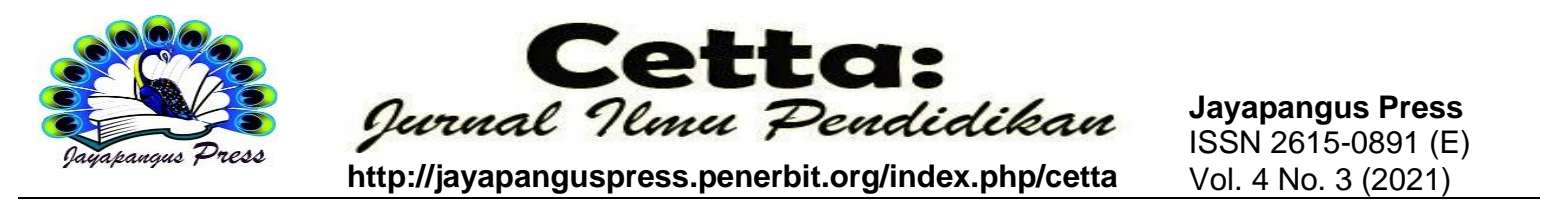

\title{
Penerapan Metode Demonstrasi Berbasis Lingkungan Untuk Meningkatkan Hasil Belajar IPA Pada Siswa Kelas VI Satuan Pendidikan SD Negeri 3 Seraya Timur
}

\author{
I Ketut Tirtayasa \\ SDN 3 Seraya Timur \\ ketuttirtayasa81@gmail.com
}

\begin{tabular}{l}
\hline Keywords: \\
\hline Environmentally \\
Based \\
Demonstration \\
Method; \\
Learning \\
outcomes \\
\hline
\end{tabular}

\begin{abstract}
This research is motivated by the low learning outcomes of grade VI students of SD Negeri 3 Seraya Timur in learning the content of science subjects. This is thought to be caused by several factors, the learning method used is still monotonous and less varied, namely only using the lecture method and the lack of learning support facilities so that learning is less effective. This classroom action research was carried out in two cycles with the aim of improving science learning outcomes. The subjects of this study were sixth grade students of SD Negeri 3 Seraya Timur with a total of 18 students consisting of 8 female students and 10 male students. Data were collected using the test method. The results of the study show that the application of environmentalbased demonstration methods in science learning can improve student learning outcomes. Based on the initial reflection analysis, the average learning outcome reaches 60.00 and the percentage of learning outcomes reaches $60.00 \%$ in the poor category. While in the first cycle, the average learning outcomes reached 73.61 and the percentage of learning outcomes reached 73.61\%. This percentage shows on a good scale. While in the second cycle, the average learning outcomes in the second cycle reached 82.78 and the percentage of learning outcomes reached $82.78 \%$. This percentage shows in the very good category. From the explanation above, this research has been able to answer the problem formulation as well as being able to solve the problem of the low science learning outcomes of sixth grade students of SD Negeri 3 Seraya Timur. This is also supported by an increase in student learning activity towards the learning carried out, in other words, the classroom action research has been successful.
\end{abstract}

Kata Kunci:

Metode

Demonstrasi

Berbasis

Lingkungan;

Hasil Belajar

\begin{abstract}
Abstrak
Penelitian ini dilatarbelakangi oleh rendahnya hasil belajar siswa kelas VI SD Negeri 3 Seraya Timur pada pembelajaran muatan mata pelajaran IPA. Hal ini diduga disebabkan oleh beberapa faktor, metode pembelajaran yang digunakan masih monoton kurang bervariasi, yaitu hanya menggunakan metode ceramah
\end{abstract}


dan kurangnya sarana pendukung pembelajaran sehingga pembelajaran kurang efektif. Penelitian tindakan kelas ini dilaksanakan dalam dua siklus dengan tujuan meningkatkan hasil belajar IPA. Subyek penelitian ini adalah siswa kelas VI SD Negeri 3 Seraya Timur dengan jumlah siswa 18 orang yang terdiri dari 8 siswa perempuan dan 10 laki-laki. Data dikumpulkan dengan menggunakan metode tes. Hasil penelitian menunujukkan bahwa penerapan metode demonstrasi berbasis lingkungan dalam pembelajaran IPA dapat meningkatkan hasil belajar siswa, Berdasarkan analisis refleksi awal rata-rata hasil belajar mencapai 60,00 dan persentase tingkat hasil belajar mencapai 60,00\% dalam kategori kurang. Sedangkan pada siklus I yaitu rata-rata hasil belajar mencapai 73,61 dan Persentase tingkat hasil belajar mencapai $73,61 \%$. Persentase ini menunjukkan pada skala baik. Sedangkan pada siklus II, ratarata hasil belajar pada siklus II ini mencapai 82,78 dan persentase hasil belajar mencapai $82,78 \%$. Persentase ini menunjukkan pada kategori sangat baik, Dari paparan di atas, penelitian ini sudah mampu menjawab rumusan masalah sekaligus telah mampu memecahkan permasalahan rendahnya hasil belajar IPA siswa kelas VI SD Negeri 3 Seraya Timur. Hal ini juga didukung oleh peningkatan keaktifan belajar siswa terhadap pembelajaran yang dilakukan, dengan kata lain, penelitian tindakan kelas yang dilakukan sudah berhasil.

\section{Pendahuluan}

Metode Pembelajaran yang dilakukan oleh guru mempunyai peranan yang sangat penting dalam keberhasilan pendidikan. Penggunaan metode yang tepat akan mementukan keefektifan dan keefesienan dalam proses pembelajaran.Guru harus senantiasa mampu memilih dan menerapkan metode yang tepat sesuai dengan pokok bahasan yang diajarkan. Upaya yang tepat untuk menyiapkan SDM yang berkualitas dan satu-satunya wadah yang dapat dipandang dan seyogyanya berfungsi sebagai alat untuk membangun SDM yang bermutu tinggi adalah pendidikan. Pendididkan merupakan suatu kegiatan yang universal dalam kehidupan manusia.

Bertolak dari keadaan tersebut jelaslah bahwa faktor guru menempati posisi penting dalam pelaksanaan proses belajar mengajar, sehingga diperlukan pengembangan profesionalisme guru. Ini berpengaruh pada hasil belajar siswa kelas VI dilihat dari nilai ulangan harian yang diperoleh siswa kelas VI. Hasil ulangan tersebut masih belum memenuhi kriteria ketuntasan minimal muatan mata pelajaran IPA yang telah ditentukan yaitu 62. Berkaitan dengan hasil evaluasi, penulis melakukan pengamatan hasil evaluasi kelas VI semester ganjil tahun pelajaran 2019/2020. Jika diteliti, permasalahan- 
permasalahan tersebut muncul dari keseharian siswa di kelas. Khususnya di Satuan Pendidikan SD Negeri 3 Seraya Timur tempat penelitian ini banyak sekali ditemukan permasalahan. Seperti dalam pembelajaran IPA. Dalam pembelajaran, siswa kurang antusias dan kurang peduli terhadap apa yang disampaikan guru, mereka lebih mementingkan hal lain dari pada belajar, seperti menggambar, bicara sendiri dengan teman di dekatnya.

Menyikapi kondisi akademik tersebut diatas maka perlu diupayakan usaha peningkatan penguasaan siswa terhadap konsep-konsep IPA dengan menerapkan metode demonstrasi berbasis lingkungan. Metode Demonstrasi sangat dibantu dengan memanfaatkan media lingkungan atau lingkungan dijadikan sumber belajar siswa dengan tujuan untuk meningkatkan aktivitas siswa dalam pembelajaran yang pada akhirnya meningkatkan hasil belajar khususnya tentang pemahaman konsep IPA yang diajarkan.

\section{Metode}

\section{Rancangan Penelitian}

Sesuai dengan tujuan penelitian maka tahap-tahap penelitian yang akan dilakukan adalah: refleksi awal, perencanaan, pelaksanaan, observasi, refleksi, dan laporan. Kemmis dan Mc. Taggart (Arikunto, 2002) menyatakan langkah penelitian tindakan merupakan bentuk siklus spiral yang mulai dari perencanaan, tindakan, pengamatan dan refleksi. Penelitian ini menggunakan rancangan penelitian tindakan

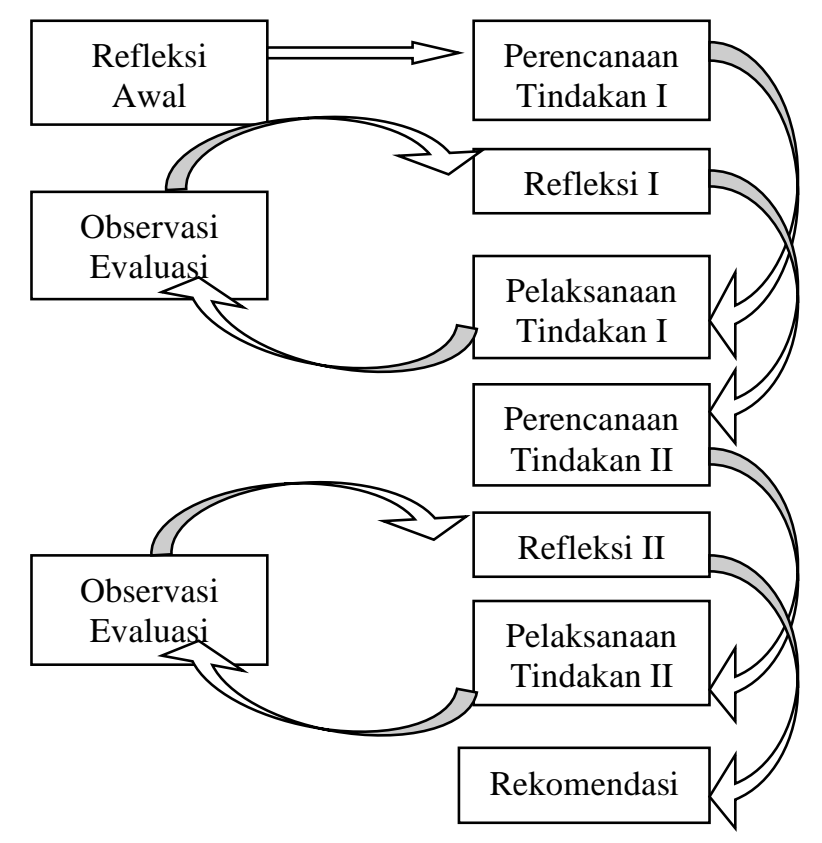

Gambar 1. Skema desain penelitian Tindakan dimodifikasi dari Kemmis and Taggart (Wardhani, $2006:$ 37) 
Penelitian ini menggunakan rancangan penelitian tindakan kelas (PTK). Arikunto (2006) menyatakan bahwa “ penelitian tindakan kelas adalah suatu pencermatan terhadap kegiatan belajar berupa sebuah tindakan yang sengaja dimunculkan dan terjadi dalam sebuah kelas secara bersamaan".

\section{Subyek dan Objek Penelitian}

Subjek penelitian adalah orang yang dikenai tindakan". Dengan kata lain, subjek adalah tempat data penelitian itu diperoleh. Penelitian ini dilaksanakan di Satuan Pendidikan SD Negeri 3 Seraya Timur, tepatnya adalah di kelas VI dengan jumlah siswa 41 orang yang terdiri dari 15 siswa perempuan dan 26 laki-laki. Objek dalam penelitian ini ini adalah metode demonstrasi berbasis lingkungan dalam pembelajaran IPA. Sementara itu, objek yang mencerminkan produk adalah hasil belajar siswa dalam pembelajaran IPA.

\section{Teknik Analisis Data}

Berdasarkan data yang terkumpul kemudian dilakukan analisis atau pengolahan data. Teknik analisis data pada penelitian ini bertujuan untuk menentukan hasil belajar IPA siswa kelas VI Satuan Pendidikan SD Negeri 3 Seraya Timur tahun pelajaran 2019/2020.Data hasil belajar siswa secara individu diolah sebagai berikut.Peneliti melakukan penjumlahan nilai yang diperoleh siswa, yang selanjutnya dibagi dengan jumlah siswa yang ada di kelas tersebut sehingga diperoleh rata-rata tes formatif dapat dirumuskan.

$$
\bar{X}=\frac{\sum X}{\sum N}
$$

Dengan $: \bar{X} \quad=$ Nilai rata-rata

$$
\Sigma \mathrm{X}=\text { Jumlah semua nilai siswa }
$$$$
\Sigma \mathrm{N}=\text { Jumlah siswa }
$$

\section{Ketuntasan Belajar}

Ada dua kategori ketuntasan belajar yaitu secara perorangan dan secara klasikal. Berdasarkan petunjuk pelaksanaan belajar mengajar kurikulum 1994 (Depdikbud, 1994), yaitu seorang siswa telah tuntas belajar bila telah mencapai skor 62, dan kelas disebut tuntas belajar bila di kelas tersebut terdapat $85 \%$ yang telah mencapai daya serap lebih 
dari atau sama dengan $62 \%$. Untuk menghitung persentase ketuntasan belajar digunakan rumus sebagai berikut.

$$
\mathrm{KKB}=\frac{\text { Jumlah siswa tuntas }}{\text { Jumlah siswa keseluruhan }} \times 100 \%
$$

Keterangan :

$\mathrm{KKB}=$ Kriteria Ketuntasan Belajar

Daya serap siswa diperoleh dengan rumus berikut.

$$
\text { DS }=\frac{\text { Nilai Rata- rata Kelas }}{\text { Nilai Tertinggi ideal (100) }} \times 100
$$

\section{Indikator Keberhasilan}

Penelitian tindakan kelas untuk mengetahui hasil belajar siswa dikatakan berhasil apabila hasil belajar IPA secara individu telah memperoleh nilai minimal 62 sesuai dengan KKM yang ditentukan di satuan pendidikan SD Negeri 3 Seraya Timur dan secara klasikal sudah mencapai ketuntasan minimal 85\% dari jumlah seluruh siswa.

\section{Hasil Dan Pembahasan}

\section{Hasil Penelitian Pra Siklus}

Dari analisis refleksi awal ternyata nilai rata-rata kelas hanya sebesar 59,51 dan persentase tingkat hasil belajar atau daya serap hanya mencapai 59,51\% sedangkan ketuntasan belajar siswa hanya mencapai $43,90 \%$ atau berada dalam ketegori tidak tuntas,dari 41 siswa hanya 18 orang siswa dikatakan tuntas, sehingga menjadi perhatian dalam pelaksanaan pada siklus I pada penelitian ini untuk ditingkatkan dengan penerapan metode demonstrasi berbasis lingkungan dalam pembelajaran muatan mata pelajaran IPA siswa kelas VI Satuan Pendidikan SD Negeri 3 Seraya Timur Semester ganjil tahun pelajaran 2019/2020 Merujuk pada kelemahan-kelemahan yang dialami pada siklus I, maka semua permasalahan ini peneliti mencoba mencari titik permasalahannya dalam kegiatan refleksi. Selanjutnya dilakukan rancangan perbaikan tindakan untuk dijadikan perbaikan pada siklus II.

Adapun perbaikan-perbaikan tersebut diantaranya sebagai berikut : peneliti akan memperbaiki beberapa langkah pembelajaran. Pada tahap pendahuluan, peneliti akan memberikan arahan kepada siswa agar lebih serius dalam belajar. Selain itu, pada tahap 
kegiatan inti, peneliti akan memberikan perhatian yang penuh terhadap siswa yang tidak memperhatikan penjelasan materi terutama pada tahap teach dengan cara memberikan pertanyaan langsung kepada siswa yang bersangkutan. Selanjutnya, pada tahap pengamatan lingkungan, peneliti akan mengawasi keaktifan siswa agar tidak ada siswa yang hanya meniru pekerjaan temannya. Kemudian, terkait dengan masalah kesiapan siswa, peneliti akan lebih tekun mengingatkan siswa agar tidak lupa membawa sarana yang dibutuhkan, misalnya buku catatan, buku paket, dan yang lainnya. Selain itu, peneliti akan lebih mengefektifkan media lingkungan sekitar dalam pembelajaran.

a. Siklus 1

Berdasarkan perhitungan setelah dilaksanakan tindakan pada Siklus I dapat diperoleh hasil bahwa secara klasikal, ketuntasan belajar siswa hanya mencapai 65,85\%. Hal ini menunjukkan bahwa hasil belajar siswa kelas VI Satuan Pendidikan SD Negeri 3 Seraya Timur masih di bawah target yang peneliti tetapkan. Sementara itu, rata-rata siswa adalah sebesar 74,39 dan daya serap siswa terhadap materi IPA adalah hanya 74,39\%. Apabila dimasukkan ke dalam konversi rata-rata skor kemampuan pemahaman konsep maka hasil daya serap yang diperoleh siswa kelas VI Satuan Pendidikan SD Negeri 3 Seraya Timur sudah tergolong baik.

Merujuk pada kelemahan-kelemahan yang dialami pada siklus I, maka semua permasalahan ini peneliti mencoba mencari titik permasalahannya dalam kegiatan refleksi. Selanjutnya dilakukan rancangan perbaikan tindakan untuk dijadikan perbaikan pada siklus II. Adapun perbaikan-perbaikan tersebut diantaranya sebagai berikut : peneliti akan memperbaiki beberapa langkah pembelajaran. Pada tahap pendahuluan, peneliti akan memberikan arahan kepada siswa agar lebih serius dalam belajar. Selain itu, pada tahap kegiatan inti, peneliti akan memberikan perhatian yang penuh terhadap siswa yang tidak memperhatikan penjelasan materi terutama pada tahap teach dengan cara memberikan pertanyaan langsung kepada siswa yang bersangkutan.

Selanjutnya, pada tahap pengamatan lingkungan, peneliti akan mengawasi keaktifan siswa agar tidak ada siswa yang hanya meniru pekerjaan temannya. Kemudian, terkait dengan masalah kesiapan siswa, peneliti akan lebih tekun mengingatkan siswa agar tidak lupa membawa sarana yang dibutuhkan, misalnya buku catatan, buku paket, dan yang lainnya. Selain itu, peneliti akan lebih mengefektifkan media lingkungan sekitar dalam pembelajaran. 


\section{b. Siklus II}

Berdasarkan perhitungan setelah dilaksanakan tindakan pada Siklus II, dapat diperoleh hasil bahwa secara klasikal, ketuntasan belajar siswa mencapai 95,12\% atau 39 dari 41 siswa dapat dikatakan tuntas. Hal ini menunjukkan bahwa hasil belajar siswa kelas VI Satuan Pendidikan SD Negeri 3 Seraya Timur sudah melebihi kreteria keberhasilan yang ditetapkan dalam penelitian ini. Sementara itu, rata-rata siswa adalah sebesar 83,66 dan daya serap siswa terhadap materi IPA adalah 83,66\%. Apabila dimasukkan ke dalam konversi rata-rata skor kemampuan konsep, maka hasil daya serap yang diperoleh siswa kelas VI Satuan Pendidikan SD Negeri 3 Seraya Timur tergolong sangat baik.

Hasil penelitian secara jelas dapat dilihat dari diagram berikut yang menunjukkan terjad peningkatan yang signifikas dari refleksi awal sampai pada siklus II.

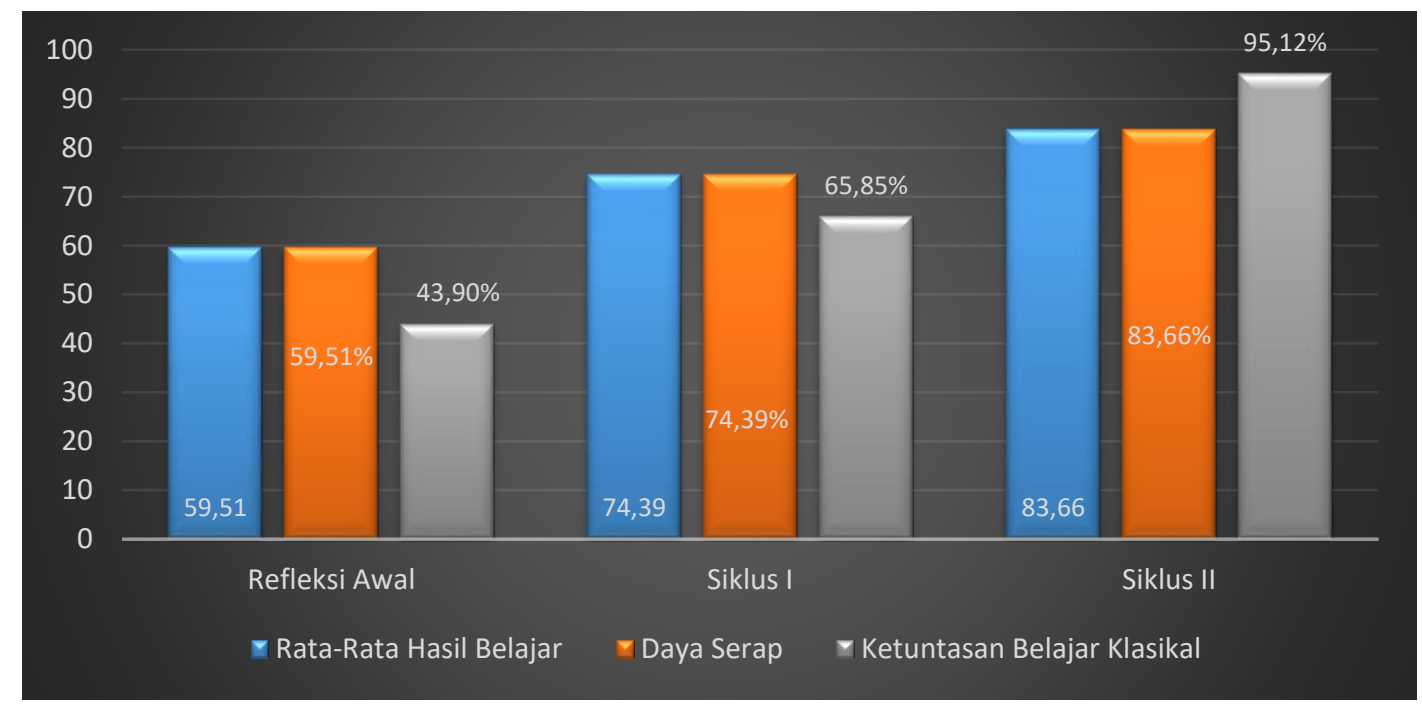

Perbaikan tindakan yang dilaksanakan pada siklus II ternyata secara kuantitas dapat meningkatkan kemampuan pemahaman siswa terhadap konsep IPA.Rata-rata skor hasil belajar siswa pada siklus II yaitu 83,66 dan berada pada kriteria sangat baik. Jika dibandingkan dengan hasil siklus I, pada siklus II ini terjadi peningkatan sebesar $24,15 \%$ dari pra siklus. Hasil yang diperoleh pada siklus II ini telah memenuhi target keberhasilan yang diharapkan. Dari paparan di atas, secara umum penelitian ini telah mampu menjawab permasalahan penelitian sebagaimana yang dirumuskan pada rumusan masalah. Hasil belajar IPA siswa kelas VI melalui pembelajaran dengan metode demonstrasi berbasis lingkungan sudah mencapai kriteria yang diharapkan .Dari penelitian ini hasil belajar siswa minimal berada pada kriteria baik, bahkan penelitian ini telah mencapai kategori sangat baik dan ketuntasan belajar mampu mencapai $95,12 \%$ tuntas. Dengan kata lain penelitian tindakan kelas yang dilakukan sudah berhasil. 
Hasil penelitian ini sejalan dengan temuan Afifi (2019), dimana peningkatan aktivitas menjawab pertanyaan guru, mengemukakan pendapat dan bertanya kepada guru dapat disebabkan oleh kesempatan yang diberikan kepada siswa cukup banyak untuk aktif secara lisan. Contohnya yaitu guru menunjuk secara langsung beberapa orang siswa untuk mengemukakan pendapat sehingga secara tidak langsung membuat siswa tersebut berusaha untuk mengemukakan suatu pendapat. Aktivitas bertanya kepada guru juga meningkat hal ini disebabkan oleh cara guru memberikan penjelasan yang merangsang siswa untuk berfikir dan menimbulkan rasa ingin tahu yang besar sehingga siswa lebih lebih aktif bertanya. Sedangkan aktivitas menjawab pertanyaan guru meningkat disebabkan oleh adanya peningkatan pemahaman siswa terhadap materi yang disampaikan sehingga siswa terlihat lebih percaya diri ketika menjawab pertanyaan.

\section{Kesimpulan}

Serangkaian kegiatan mulai dari perencanaan dan pelaksanaan kegiatan penelitian tindakan kelas akhirnya membuahkan suatu kesimpulan yaitu:Melalui penerapan metode demonstrasi berbasis lingkungan pada pembelajaran IPA dapat meningkatkan hasil belajar muatan mata pelajaran IPA siswa Kelas VI Satuan Pendidikan SD Negeri 3 Seraya Timur Semester ganjil Tahun Pelajaran 2019/2020 dengan daya serap 83,66\% yang berada pada kategori sangat baik, dan ketuntasan belajar mencapai 95,12\% yang meningkat 51,22\% dari refleksi awal ke siklus II.

\section{Daftar Pustaka}

Agung, S. (2005). Evaluasi Hasil Belajar. Diktat Perkuliahan FIK Universitas Negeri Medan

Afifi, R. (2019). Penerapan metode demonstrasi sebagai upaya meningkatkan hasil belajar siswa pada pembelajaran IPA. Jurnal Wahana Pendidikan, 4(1), 68-85.

Arikunto, S. (2006). Prosedur Penelitian Suatu Pendekatan Praktik. Jakarta : PT. Rineka Cipta.

Arikunto, S. (2003). Manajemen Penelitian. Jakarta : PT Rineka Cipta.

Arikunto, S. (2010). Prosedur Penelitian Suatu Pendekatan Praktek. Jakarta: Rineksa Cipta.

BSNP (2006). Permendiknas RI No.22 Tahun 2006 tentang Standar Isi untuk Satuan Pendidikan Dasar dan Menengah. Jakarta 
Departemen Pendidikan Nasional. (2005). Peraturan Pemerintah Nomor 19 Tahun 2005. Tentang Standar Nasional Pendidikan. Jakarta : Depdiknas

Depdikbud. (1994). Petunjuk Pelaksanaan Proses Belajar-Mengajar. Jakarta: Direktorat Pendidikan Menengah Umum

Djahiri, A. K. (1993). Membina Pendidikan Ilmu Pengetahuan Sosial PLS dan PPS yang Menjawab Tantangan Hari Esok. Jurnal Pendidikan Ilmu Pengetahuan Sosial, I/1993. Bandung: Forum Komunikasi FPIPS/IPS Indonesia.

Dwija, I Wayan. (2005). Petunjuk Penyusunan Karya Ilmiah (Bahan Ajar). Amlapura : STKIP Agama Hindu Amlapura

Hera Lestari Mikarsa (2005). Pendidikan Anak SD. Jakarta: Universitas Terbuka

Husen \& Postlethwaite. (1994). The Internatioanl Encyclopedia of Educations. Vols 112. (Second edition). Oxford: Pergamon.

Sudjana. (2006). Penilaian Hasil Proses Belajar Mengajar. Bandung: PT Remaja Rosdakarya

Purwanto. (1987). Administrasi Dan Supervisi Pendidikan. Bandung: Remadja Karya

Poerwadarminta, W. J. S. (1988). Kamus Umum Bahasa Indonesia. Jakarta : Balai Pustaka

Roestiyah, N. K. (2006) Strategi Belajar Mengajar dalam CBSA. Jakarta : Rineka Cipta Rasyidin, W. (2007). Ilmu Pendidikan Teoritik. Dalam Rujukan Filsafa, Teori dan Praktis Ilmu Pendidikan. Rochman Natawi djaya dkk (eds) Bandung. Universitas Pendidikan Indonesia Press

Rideng (2001). Penelitian Tindakan Kelas Konsep Dasar dan Model Implementasinya. Singaraja: Universitas Panji Sakti.

Riska Normalita (2010). Penelitian yang berjudul "Pengaruh Pemanfaatan Lingkungan Sekolah sebagai media pembelajaran untuk meningkatkan prestasi belajar IPA di SD Negeri 1 Tejekula Tahun Pelajaran 2010/2011

Rusyan A. T. (1993). Pendekatan Dalam Proses Belajar Mengajar yang Efektif Tingkat Pendidikan Dasar. Bandung : Bina Budaya

Suarbawa. (2001). Statistik. Yogyakarta: Fakultas Psikologi UGM

Sukardi. (2004). Metodelogi Penelitian Pendidikan. Yogyakarta : Sinar Grafika Offset Sumaji, dkk. (1998). Pendidikan Sains Yang Humanistis.Yogyakarta : Kanisius 